\title{
Growth, fatty acid composition, and reproductive parameters of diploid and triploid yellowtail tetra Astyanax altiparanae
}

\author{
Nivaldo Ferreira do Nascimento ${ }^{\mathrm{a}, \mathrm{b}, *}$, Matheus Pereira-Santos ${ }^{\mathrm{b}}$, Lucas Henrique Piva ${ }^{\mathrm{b}}$, Breno Manzini ${ }^{\mathrm{a}}$, \\ Takafumi Fujimoto ${ }^{\mathrm{c}}$, José Augusto Senhorini ${ }^{\mathrm{b}}$, George Shigueki Yasui ${ }^{\mathrm{b}}$, Laura Satiko Okada Nakaghi ${ }^{\mathrm{a}}$ \\ a Aquaculture Center, Sao Paulo State University, Via de Acesso Prof. Paulo Donato Castellane s/n, Jaboticabal, SP 14884-900, Brazil

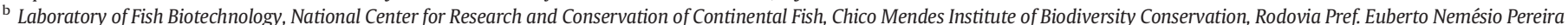 \\ de Godoy, Pirassununga, SP 13630-970, Brazil \\ ${ }^{c}$ Faculty of Fisheries Sciences, Hokkaido University, 3-1-1 Minato-cho, 041-8611 Hakodate, Japan
}

\section{A R T I C L E I N F O}

\section{Article history:}

Received 2 October 2016

Received in revised form 17 December 2016

Accepted 7 January 2017

Available online 9 January 2017

\section{Keywords:}

Astyanax altiparanae

Fatty acids

Chromosome manipulation

Growth

\begin{abstract}
A B S T R A C T
The aim of this study was to evaluate the growth, carcass yield, fatty acid composition, and reproductive parameters of diploid and triploid Astyanax altiparanae. Triploidization was induced by heat shock $\left(40{ }^{\circ} \mathrm{C}\right.$ for 2 min) 2 min after fertilization. Fish were reared for 175 days from fertilization. Triploid females showed lower proportion of saturated and poly-unsaturated fatty acids and higher amount of mono-unsaturated fatty acids than diploids. They were sterile, with immature gonads, and showed higher carcass yield than diploid females, which exhibited higher gonadosomatic indices. Triploid and diploid males showed similar gonad morphology, although diploid males produced greater numbers of spermatozoa. All males exhibited the secondary sex characteristic of spines in the pelvic and anal fins. Fatty acid composition and growth were similar in triploid and diploid males. Triploidy did not ensure sterility in males, but triploid females were sterile and had increased carcass yield, and may be used in aquaculture to increase the production of $A$. altiparanae.

Statement of relevance: To our knowledge, this is the first study addressing the effect of triploid induction on growth parameters of a neotropical species. The important results for carcass yield and sterility in female triploid will improve the production of A. altiparane, as this species is being used as live-bait for sport fishing and direct consumption.
\end{abstract}

(c) 2017 Elsevier B.V. All rights reserved.

\section{Introduction}

In aquaculture the production of sterile animals is advantageous, as it may facilitate increased growth and reduce the impact of escaped animals (Piferrer et al., 2009; Benfey, 2015). Triploidization is one of the most commonly employed techniques to produce sterile fish on a large scale (Arai, 2001; Golpour et al., 2016) and is commonly induced by suppressing the release of the second polar body through thermal, chemical, or pressure shock (Piferrer et al., 2009). As triploidy generally impairs gonad development, the energy that required for sexual maturation and reproduction in diploids can be channeled into increased growth in triploids.

However, the results of triploidy on growth are highly variable and depend on factors including fish species and environmental conditions. In some cases, the growth of triploids is similar (Sacobie et al., 2012), or lower (Friars et al., 2001), than that of diploids. Triploid fish may differ

\footnotetext{
* Corresponding author at: Aquaculture Center, Sao Paulo State University, Via de Acesso Prof. Paulo Donato Castellane s/n, Jaboticabal, SP 14884-900, Brazil.

E-mail address: nivaldotec@yahoo.com.br (N.F. do Nascimento).
}

in body composition (e.g. carcass fat), flesh yield, and fatty acid profile (Buchtova et al., 2004; Poontawee et al., 2007; Flajšhans et al., 2010; Manor et al., 2012; Ribeiro et al., 2012), variables that directly impact the acceptance of the fish in the market, and should be assessed in triploid fish intended for commercial production (Dunham, 2004).

The yellowtail tetra Astyanax altiparanae is a small $(8-14 \mathrm{~cm}$ ) characin fish of importance in neotropical aquaculture, where it is used as live bait for sport fishing and for human consumption (Garutti, 2003; Porto-Foresti et al., 2005). The species can be bred throughout the year, and sexual maturity is reached at approximately four months (Garutti, 2003; Porto-Foresti et al., 2005). Females grow faster than males and are larger at maturity; the males are smaller and develop spines on the pelvic and anal fins when sexually mature, which allows non-lethal sexing of fish (Garutti, 1990; Garutti, 2003). Due to its small size, resistance to suboptimal environmental conditions, and ease of reproduction (Porto-Foresti et al., 2005), A. altiparanae has been used in both basic and applied studies (Zaganini et al., 2012; Gonçalves et al., 2014; Siqueira-Silva et al., 2015; Yasui et al., 2015).

An artificial fertilization protocol was developed for this species (Yasui et al., 2015) enabling studies on early embryology (Pereira- 
Santos et al., 2016) and chromosome set manipulation, including the production of triploid fish (Adamov et al., 2016). Evaluation of triploid growth is important, as is determination of its potential sterility. The aim of this study was to analyze the growth, flesh yield, fatty acid composition, and reproductive aspects of diploid and triploid A. altiparanae.

\section{Materials and methods}

\subsection{Broodstock and induction of reproduction}

The study was carried out at the Instituto Chico Mendes de Conservação a Diversidade (ICMBio/CEPTA), Pirassununga-SP, Brazil. All procedures conformed to the Guide for the Care and Use of Laboratory Animals in Sao Paulo State University (CEUA/UNESP \#07919/14).

Three pairs of A. altiparanae, held in separate ponds, were used in the experiment. Artificial insemination was performed according to Yasui et al. (2015). A single injection of carp pituitary gland at $3 \mathrm{mg} \mathrm{kg}^{-1}$ body weight (BW) was administered to both males and females. Ten hours post-injection, fish were transferred to a tank containing menthol anesthesia at $\sim 100 \mathrm{mg} \mathrm{L}^{-1}$ (Êxodo Científica, Brazil). Semen was collected using a $1000 \mu \mathrm{L}$ pipette (Eppendorf, Germany) and immediately transferred a $1.5 \mathrm{~mL}$ tube containing $400 \mu \mathrm{L}$ of Ringer's solution (128.3 mM $\mathrm{NaCl}, 23.6 \mathrm{mM} \mathrm{KCl}, 3.6 \mathrm{mM} \mathrm{CaCl}_{2}, 2.1 \mathrm{mM} \mathrm{MgCl}_{2}$ ) (Yasui et al., 2015). Oocytes of females were gently stripped and collected into a Petri dish covered with polyvinylidene chloride film (Saran Wrap). Subsequently, $70 \mu \mathrm{L}$ of diluted semen was added to the eggs and activated by addition of $5 \mathrm{~mL}$ water. After $2 \mathrm{~min}$, more water was added for incubation. Fertilization was conducted separately for each broodstock pair, producing three groups of fertilized eggs.

\subsection{Triploidy induction and rearing of animals}

After activation, each group of fertilized eggs was divided into two portions: one heat shocked at 2 min post-fertilization to induce triploidy $\left(40^{\circ} \mathrm{C}, 2 \mathrm{~min}\right)$ and an untreated control. Water temperature in the time period between fertilization and heat shock was $26{ }^{\circ} \mathrm{C}$. Eggs were incubated separately in six $40 \mathrm{~L}$ aquaria (3 diploid and 3 triploid) for hatching and rearing of larvae. Larvae were fed exclusively with Artemia sp. until 30 days post-hatching (dph), after which dry food was included until $40 \mathrm{dph}$. Tanks were monitored and dead larvae removed.

At $40 \mathrm{dph}$, each portion of larvae was transferred to a $125 \mathrm{~L}$ aquarium at a stocking density of 120 fish per aquarium (total of 720 ) in a recirculation system with water temperature of $28{ }^{\circ} \mathrm{C}$ and $12 \mathrm{~h}: 12 \mathrm{~h} \mathrm{~L}: \mathrm{D}$ regime. The position of aquaria was randomly determined, and fish were fed on commercial pellets ( $1 \mathrm{~mm}, 91.62 \%$ dry matter, $45 \%$ crude protein, $8 \%$ crude fat, $2.8 \%$ crude fiber and mineral matter $12.10 \%$ ) twice daily to apparent satiation.

\subsection{Growth measurement, evaluation of reproductive performance and carcass characteristics}

At 52, 83, 114, 144, and $175 \mathrm{dph}$, we haphazardly selected 10 fish from each aquarium $(n=60)$. Fish were euthanized with prolonged anesthesia in $\sim 100 \mathrm{mg} \mathrm{L}^{-1}$ menthol (Êxodo Científica, Brazil), and the standard length (SL, mm) body weight (BW, g), viscerosomatic (VSI, without gonads) and gonadosomatic indices (GSI) were assessed. The carcass weight was measured to determine yield (\% of BW). The growth of males and females was evaluated separately, with sex determined by histological observation of gonads.

The gonads were fixed in Bouin's fixative for $24 \mathrm{~h}$ and stored in 70\% ethanol prior to histological processing at the Department of Animal Morphology and Physiology of the Faculty of Agrarian and Veterinary Sciences, Univ Estadual Paulista (UNESP), Jaboticabal-SP, Brazil. The gonads were washed in $70 \%$ ethanol and subsequently dehydrated through increasing ethanol series (70,80,90, and 100\%), cleared in xylene, and embedded in paraffin. The sections ( $5 \mu \mathrm{m})$ were stained with hematoxylin and eosin and analyzed microscopically (Axioplan 2, ZEISS, USA) equipped with a CCD camera (MC 80 DX, ZEISS, USA)

Just from 114 dph onwards, when sexual maturation of diploid males and females was observed, analysis was conducted to compare gonad development in diploid and triploid fish $(n=180)$. In males, the seminiferous tubules were checked for spermatozoa, while, in females, the presence of mature (containing vitellogenic oocytes) or immature ovaries (cells undergoing primary growth) was recorded. Of the 180 gonad samples analyzed (114 dph onwards), 16 were lost during processing, and the haphazard sampling resulted in more males $(\mathrm{n}=112)$ than females $(\mathrm{n}=52)$ being selected for analysis. During the growth trial, stocking densities were not adjusted.

For observation of spines, anal fins were fixed in 5\% formalin and diafanized according to a protocol adapted from Potthoff (1984). The fins were washed in distilled water $(24 \mathrm{~h})$, dehydrated in increasing concentrations of ethanol (50\% and 90\%, 24 h each), and stained with $30 \%$ Alcian blue diluted with $60 \%$ absolute ethanol and $40 \%$ acetic acid for $24 \mathrm{~h}$ for cartilage staining. Fish were subsequently placed in a saturated Borate solution for $5 \mathrm{~h}$, a whitening solution of $3 \% \mathrm{H}_{2} \mathrm{O}_{2}$ in $\mathrm{KOH}$ $2 \%$ for $2 \mathrm{~h}$, and a clarifying solution of $35 \%$ saturated borate and $65 \%$ $\mathrm{H}_{2} \mathrm{O}_{2}$ for $7 \mathrm{~h}$. Subsequently, samples were placed in a bone staining solution (alizarin $2 \%$ in $\mathrm{KOH} 2 \%$ solution) for $24 \mathrm{~h}$ and then transferred to preservation solution I (Glycerine 30\% + $\mathrm{KOH} 2 \%$ ) for $24 \mathrm{~h}$, preservation solution II (Glycerine 60\% $+\mathrm{KOH} 2 \%$ ) for $24 \mathrm{~h}$, and finally into a glycerine + thymol maintenance solution.

At the end of the experimental period, 2 fish of each sex and ploidy were haphazardly selected from each aquarium (plus one additional diploid female) for calculation of carcass fatty acid profile. Fish were frozen at $-18{ }^{\circ} \mathrm{C}$ until analysis. The total lipid extraction method was conducted according to Bligh and Dyer (1959) and methylation according to the official method Ce2-66: Preparation of methyl esters of long chain fatty acids was according to Firestone (2009). The fatty acid profile was obtained using a gas chromatograph CG-14B (Shimadzu) with fused silica OMEGAWAX 250 capillary column $(30 \mathrm{~m} \times 0.25 \mathrm{~mm} \times 0.25 \mu \mathrm{m})$ and a flame ionization detector (FID). The temperature of the column was set at $100{ }^{\circ} \mathrm{C}$ for $2 \mathrm{~min}$, followed by an increase of $4{ }^{\circ} \mathrm{C} \mathrm{min}-1$ to $220^{\circ} \mathrm{C}$ held for $25 \mathrm{~min}$. The injection and detection temperatures were $250{ }^{\circ} \mathrm{C}$ and $280{ }^{\circ} \mathrm{C}$, respectively. The carrier gas $\left(\mathrm{H}_{2}\right)$ flow was set at $1 \mathrm{~mL} \mathrm{~min}{ }^{-1}$ and a dose of $1 \mu \mathrm{L}$.

\subsection{Ploidy analysis}

A fragment of caudal fin from each fish used in the growth evaluation was collected for ploidy analysis $(n=300)$. The relative DNA content was measured by flow cytometry, and the ploidy of presumptive triploid fish was confirmed by comparison with the diploid control. The caudal fin fragment was placed into lysis solution $(9.53 \mathrm{mM}$ $\mathrm{MgSO}_{4} \cdot 7 \mathrm{H}_{2} \mathrm{O}, 47.67 \mathrm{mM} \mathrm{KCl}, 15 \mathrm{mM}$ Tris, $74 \mathrm{mM}$ Sucrose, $0.8 \%$ Triton $\mathrm{X}-100$ ) for $10 \mathrm{~min}$, and the resulting nuclear suspension was stained using $800 \mu \mathrm{L}$ of 4 ',6-Diamidino-2-phenylindole dihydrochloride-DAPI ( $1 \mu \mathrm{g} \mathrm{mL} \mathrm{m}^{-1}$ of reDAPI in Dulbecco's phosphate buffered saline). The samples were filtered through $30 \mu \mathrm{m}$ nylon mesh and analyzed by flow cytometry (CyFlow Ploidy Analyzer, Partec, GMBh, Germany).

\subsection{Statistical analysis}

The results were expressed as mean \pm standard error. Data were checked for normality using the Lilliefors test. Each family was separated in two groups ( $2 n$ and $3 n$ ) and tank effect was not evaluated. The data for growth and somatic parameters were analyzed by ANOVA, considering the effect of time, ploidy and the interaction (time $\times$ ploidy). The data for fatty acids were also analyzed by ANOVA, considering the 
effect of sex, ploidy and the interaction ( $\operatorname{sex} \times$ ploidy). Analysis was performed using the software STATISTICA v. 10.0 (Statsoft, Tulsa, U.S.A.) and significance was set at $P<0.05$.

\section{Results}

\subsection{Ploidy analysis and survival}

We analyzed ploidy of 300 fish: 150 controls and 150 heat shocked fish (presumptive triploids). All control fish were diploid. In the heatshocked groups, 11 fish were determined to be diploid, giving triploidization success of $92.7 \%$. In the assessment of each parameter, just confirmed $3 \mathrm{n}$ fish were used. During the experiment, no significant mortality was observed in any group. A total of 388 fish survived at 175 days (In addition to the euthanized fish for carcass traits, 17 diploids and 15 triploids died among the sampling dates).

\subsection{Length and weight}

There was no effect of ploidy on length and weight of females $(P=$ 0.1366 and $P=0.2906)$, but both increased over time, which had a significant effect $(P=0.0000)$ (Fig. $1 \mathrm{~A}, \mathrm{~B})$. In males, just time had a significant effect on length $(P=0.0000)$ (Fig. $1 \mathrm{~A})$. For weight, time $(P=$ $0.0000)$ and ploidy $(P=0.0030)$ had a significant effect, with triploid fish presenting higher values (Fig. 1B).

\subsection{Carcass yield}

Time $(P=0.0000)$, ploidy $(P=0.0000)$ and time $\times$ ploidy $(P=$ 0.0000 ) had a significant effect on carcass yield of females and higher values for triploid fish were evident from 114 to $175 \mathrm{dph}$ (Fig. 2A). In males, just time had a significant effect $(P=0.0000)$ and no difference

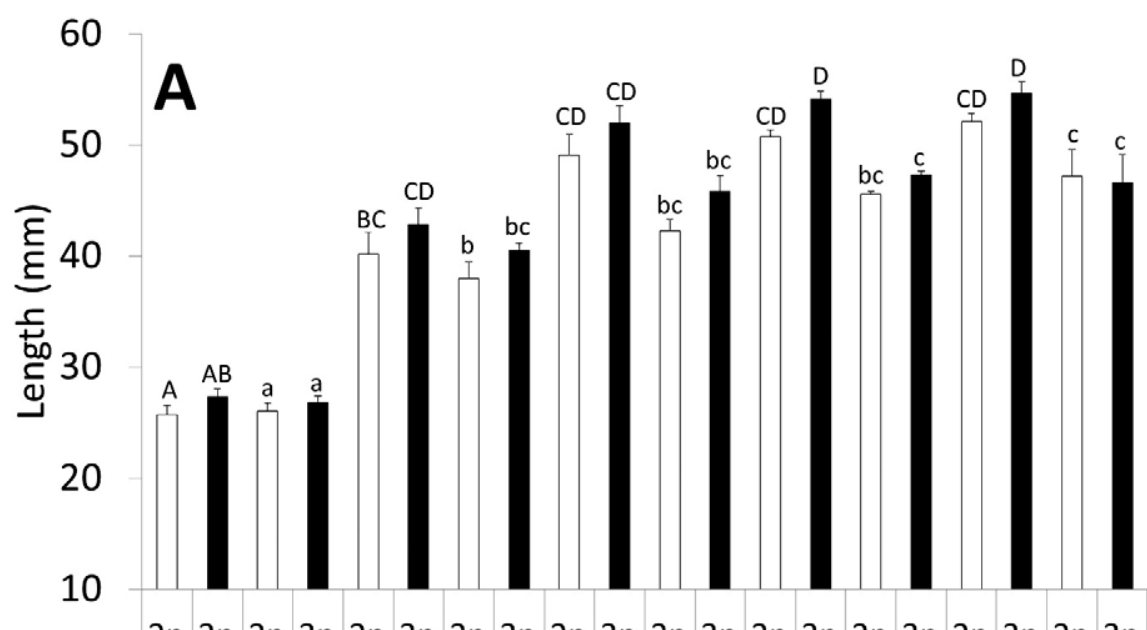

$2 n 3 n 2 n 3 n 2 n 3 n 2 n 3 n 2 n 3 n 2 n$ 3n $2 n$ 3n $2 n$ 3n $2 n$ 3n $2 n 3 n$
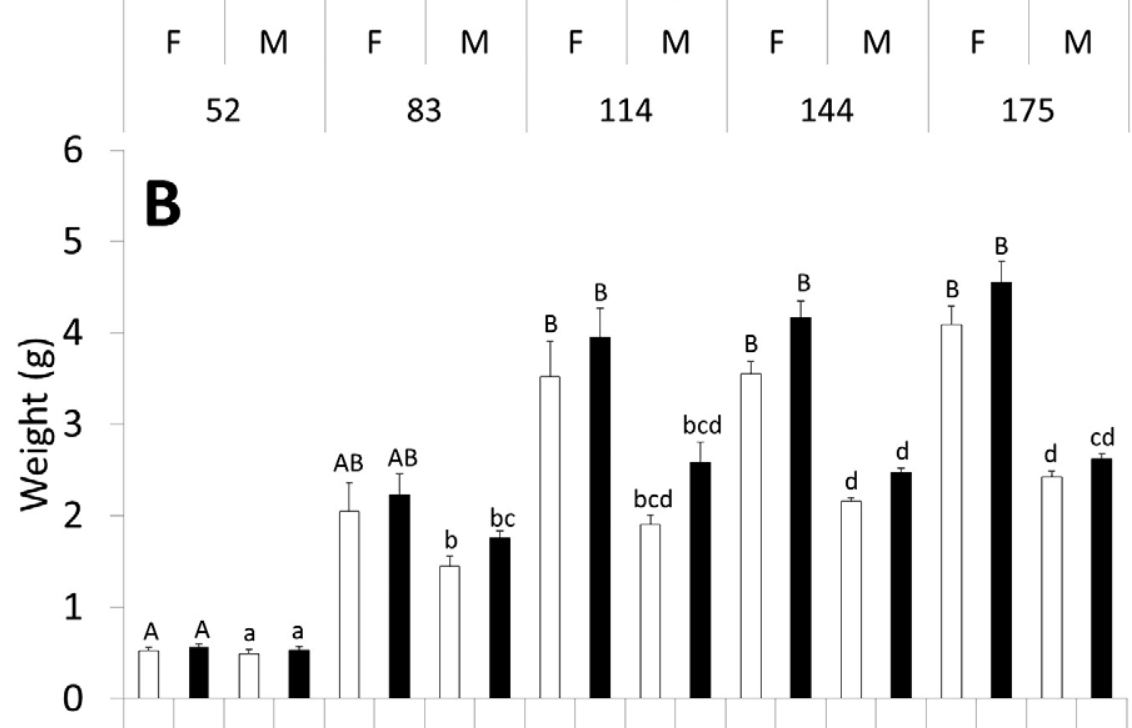

$2 n 3 n 2 n 3 n 2 n 3 n 2 n 3 n 2 n 3 n 2 n 3 n 2 n 3 n 2 n 3 n 2 n 3 n 2 n 3 n$

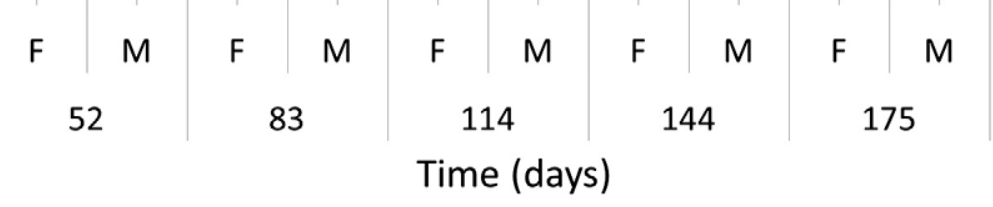

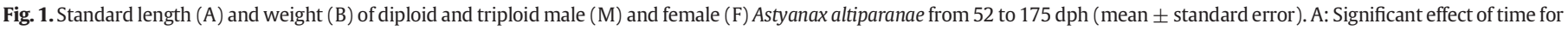

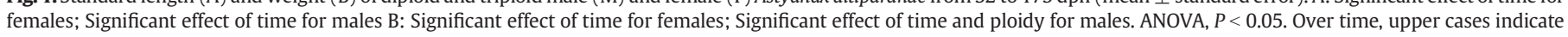
differences between females and lower cases between male. Female $2 n(n=71)$, female $3 n(n=60)$, male $2 n(n=82)$ and male $3 n(n=87)$. 

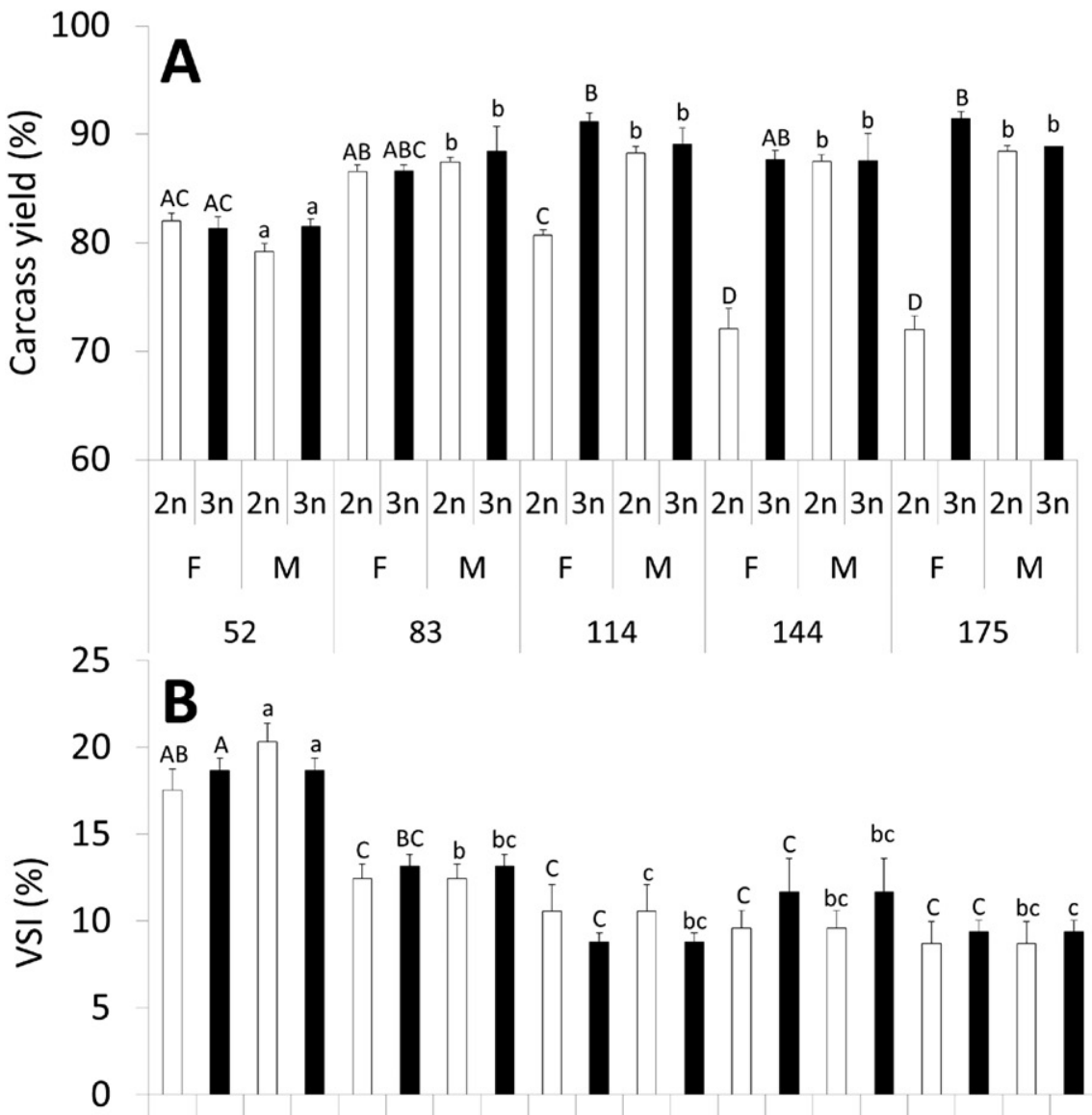

$2 n 3 n 2 n 3 n 2 n 3 n 2 n 3 n 2 n 3 n 2 n 3 n 2 n$ 3n $2 n$ 3n $2 n$ 3n $2 n 3 n$

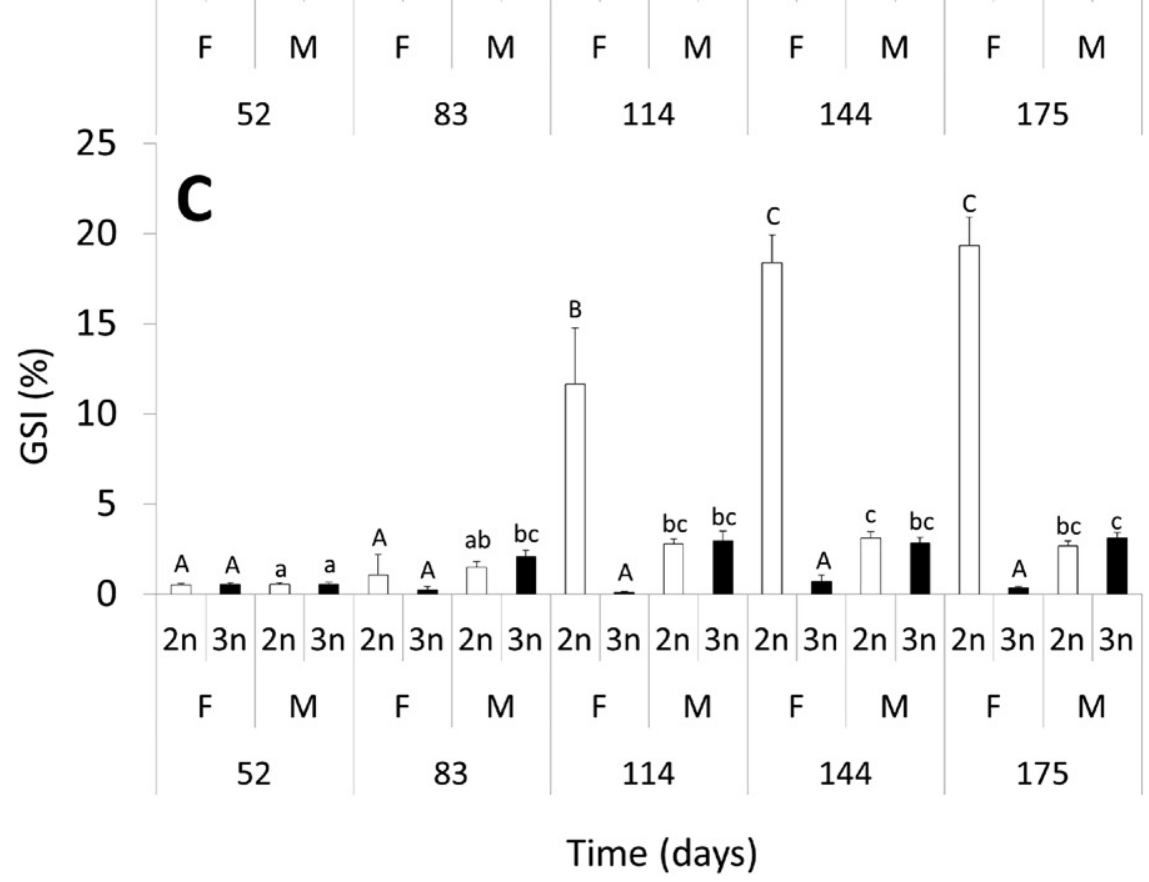

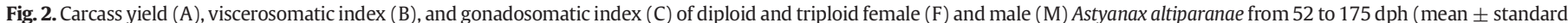

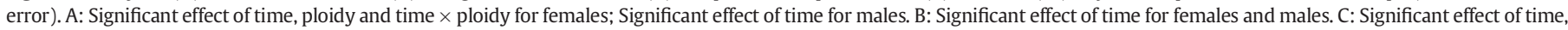

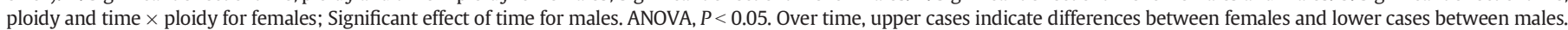
Female $2 n(n=71)$, female $3 n(n=60)$, male $2 n(n=82)$ and male $3 n(n=87)$. 
$(P=0.0541)$ was observed between diploid and triploid fish throughout the experiment (Fig. 2A).

\subsection{Viscerosomatic and gonadosomatic indices}

A significant effect of time were observed for VSI in males $(P=$ $0.0000)$ and females $(P=0.0000)$ and no difference $(P=0.0541)$ was observed between diploid and triploid fish throughout the experiment (Fig. 2B).

For GSI, time $(P=0.0000)$, ploidy $(P=0.0000)$ and time $\times$ ploidy $(P=0.0000)$ had a significant effect on females and from 114 to 175 dph triploid fish showed extremely lower values compared to diploid (Fig. 2C). In males, just time had a significant effect $(P=0.0000)$ and no difference $(P=0.3670)$ was observed between diploid and triploid fish throughout the experiment (Fig. 2C).

Macroscopically, triploid females showed decreased ovarian development when compared with diploid females (Fig. 3A, B), while diploid and triploid males had morphologically similar gonads (Fig. 3C, D).

\subsection{Diaphanization}

At 52 dph no analyzed fish exhibited pelvic or anal fin spines. From $83 \mathrm{dph}$, both diploid and triploid males developed spines in the pelvic and anal fins (Fig. 4A-D).

\subsection{Histology}

Diploid and triploid female gonads differed histologically. The gonads of diploid females $(n=26)$ contained pre-vitellogenic and several vitellogenic oocytes (Fig. 5A, B). Conversely, most gonads of triploid females were immature and contained pre-vitellogenic oocytes and oogonia nests (22 of 26 fish; Fig. 5C, D). A few vitellogenic oocytes were present in the gonads of four immature triploid females (Fig. 5E).

All stages of testicular germ cells (spermatogonia, spermatocyte, spermatids, and spermatozoa) were observed in both diploid and triploid male gonads. Nearly all diploid males ( 53 of 59 fish) had large numbers of spermatozoa within the lumen of the seminiferous tubules (Fig. $6 \mathrm{~A}, \mathrm{~B})$, but few spermatozoa were observed in the other six specimens. In triploid males, most gonads (47 of 53 fish) showed absence or small numbers of spermatozoa (Fig. 6C, D). The other six triploid males showed testicular histology similar to that of diploid males with the lumen of the seminiferous tubules containing a large numbers of spermatozoa (Fig. 6E).

\subsection{Fatty acids}

The fatty acid composition of the carcass with respect to ploidy, sex and the interaction ( F 2n, M 2n, F 3n, M 3n) is show in Table 1. In general, the greatest differences were observed between diploid and triploid females.

Ploidy had a significant effect on $(P=0.0009)$ saturated fatty acid (SFA), with diploid fish present greater proportions than triploid fish, especially palmitic acid (C16:0) in diploid females $(P=0.0051)$. Triploid fish of both sexes showed lower proportions of pentadecanoic acid (C15:0), palmitic acid (C16:0) than did diploids. For Arachidic acid (C20:0) ploidy $(P=0.0045)$ and $\operatorname{sex}(P=0.0008)$ had a significant effect, and the values was lower in triploid females.

The highest proportions of mono-unsaturated fatty acids (MUFA) were observed in triploid fish, with a significant effect of ploidy $(P=$ $0.0012)$. The high proportions of methyl ester (C18:1n9c) in triploid females was most likely the major factor in the overall MUFA results $(P=$ 0.0012 ). Diploid males and females both showed low proportions of MUFA ( $P=0.0013)$, especially eicosenoic acid (C20:1n9c) in females.

Ploidy had a significant effect on proportions of poly-unsaturated fatty acids (PUFA), with triploid fish presenting lower $(P=0.0158)$ proportions, especially C20:5n3, C20:4n6, C18:3n6, C18:3n3 C20:3n6, and $\mathrm{C} 18: 2 \mathrm{n} 6 \mathrm{c}$ in females. Diploid females showed greater $(P=0.0033)$ total $\mathrm{n} 6$ fatty acid proportions than did triploid females. Diploid males showed greater $(P=0.0162)$ proportions of $n 3$ fatty acids than did triploid females, but proportions similar to those of triploid males $(P=$ $0.4892)$ and diploid females $(P=0.8694)$.

\section{Discussion}

Although protocols for triploidization exists (Foresti et al., 1994; Huergo and Zaniboni-Filho, 2006), to our knowledge, this is the first study addressing the effect of triploid induction on growth parameters of a neotropical species. We observed significantly greater carcass yield of triploid females than of diploids. This is probably related to the extremely low gonadosomatic index of the triploid females, indicating that the energy not directed to reproduction was channeled to somatic growth (Koedprang and Nakorn, 2000; Lutz, 2003; Dunham, 2004). While triploid females showed lower GSI, an increase was
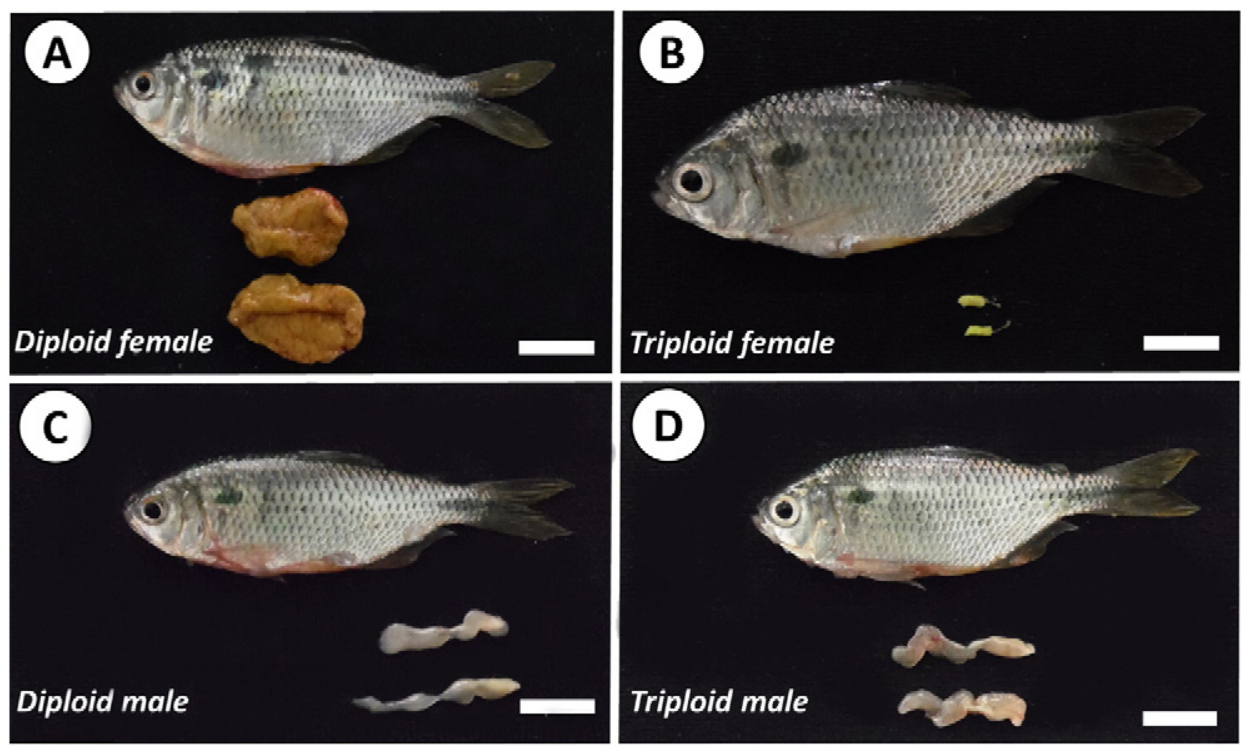

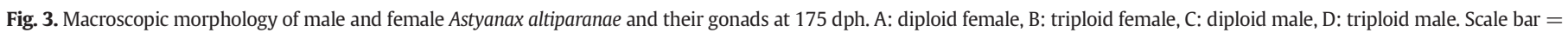
$1 \mathrm{~cm}$. 

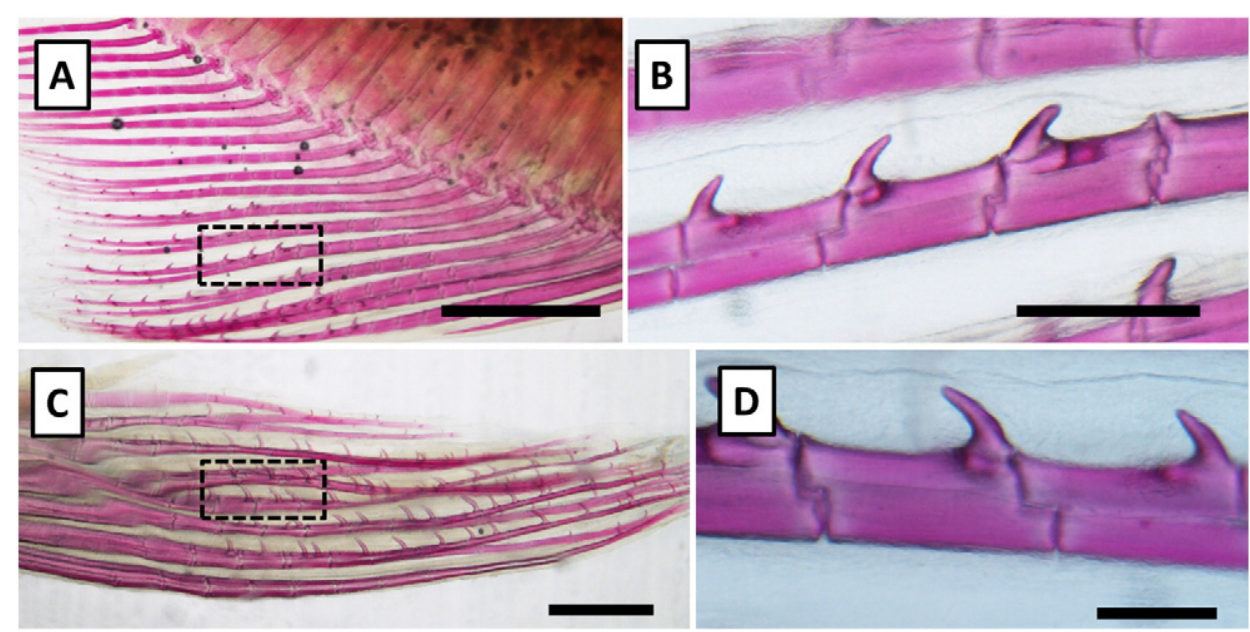

Fig. 4. Anal and pelvic fins of diploid Astyanax altiparanae males at $83 \mathrm{dph}$ demonstrated by diafanization. A and B: anal fin rays at $83 \mathrm{dph}$; C and D: pelvic fin rays at $83 \mathrm{dph}$. Scale A and C: $1000 \mu \mathrm{m} ; \mathrm{B}: 200 \mu \mathrm{m} ; \mathrm{D}: 100 \mu \mathrm{m}$.
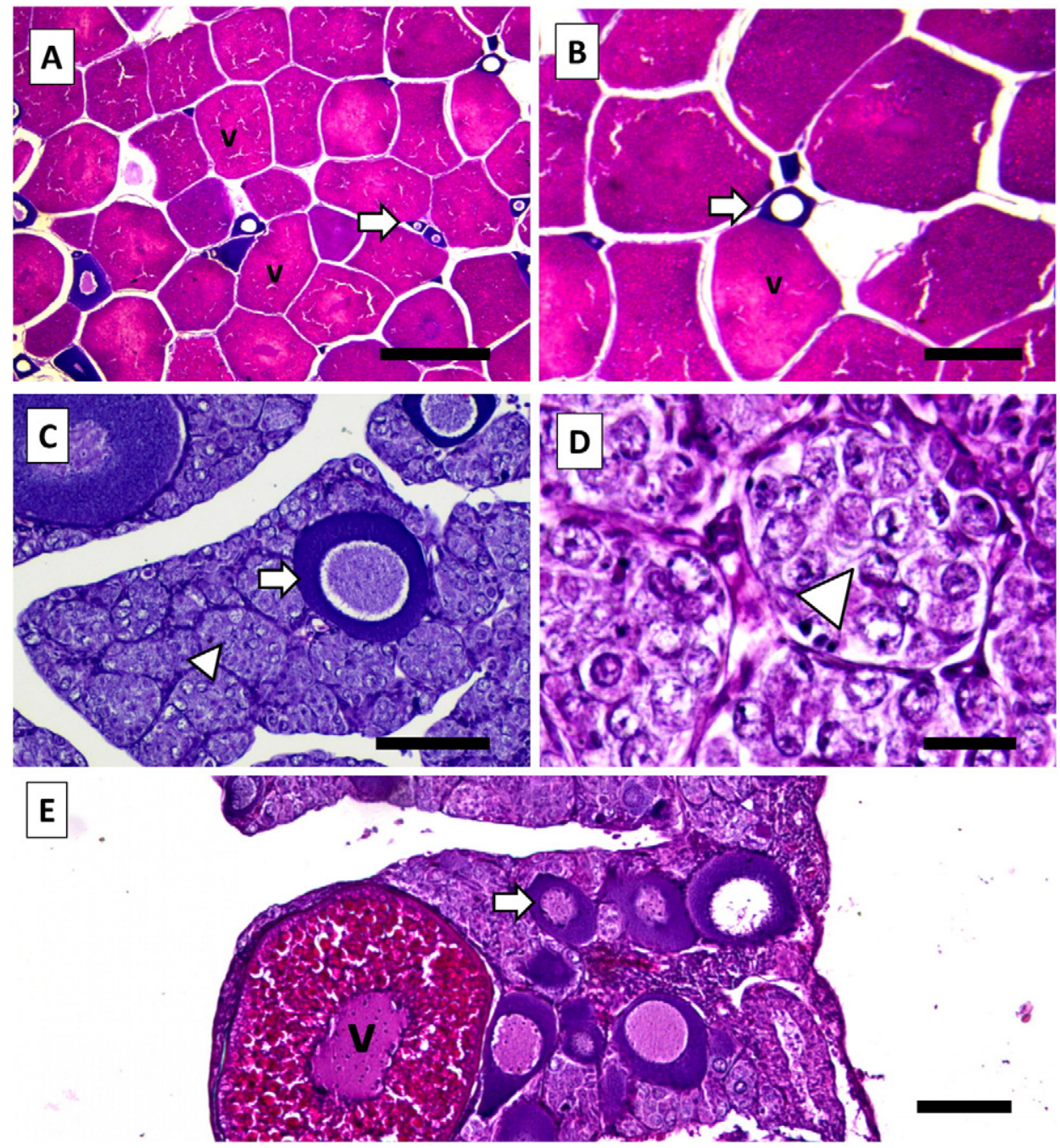

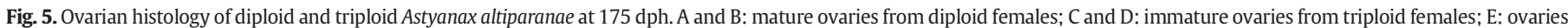

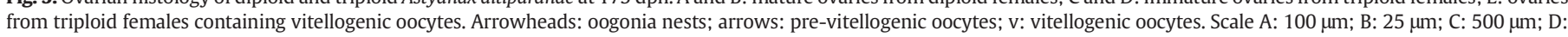
$250 \mu \mathrm{m} ; \mathrm{E}: 100 \mu \mathrm{m}$. 

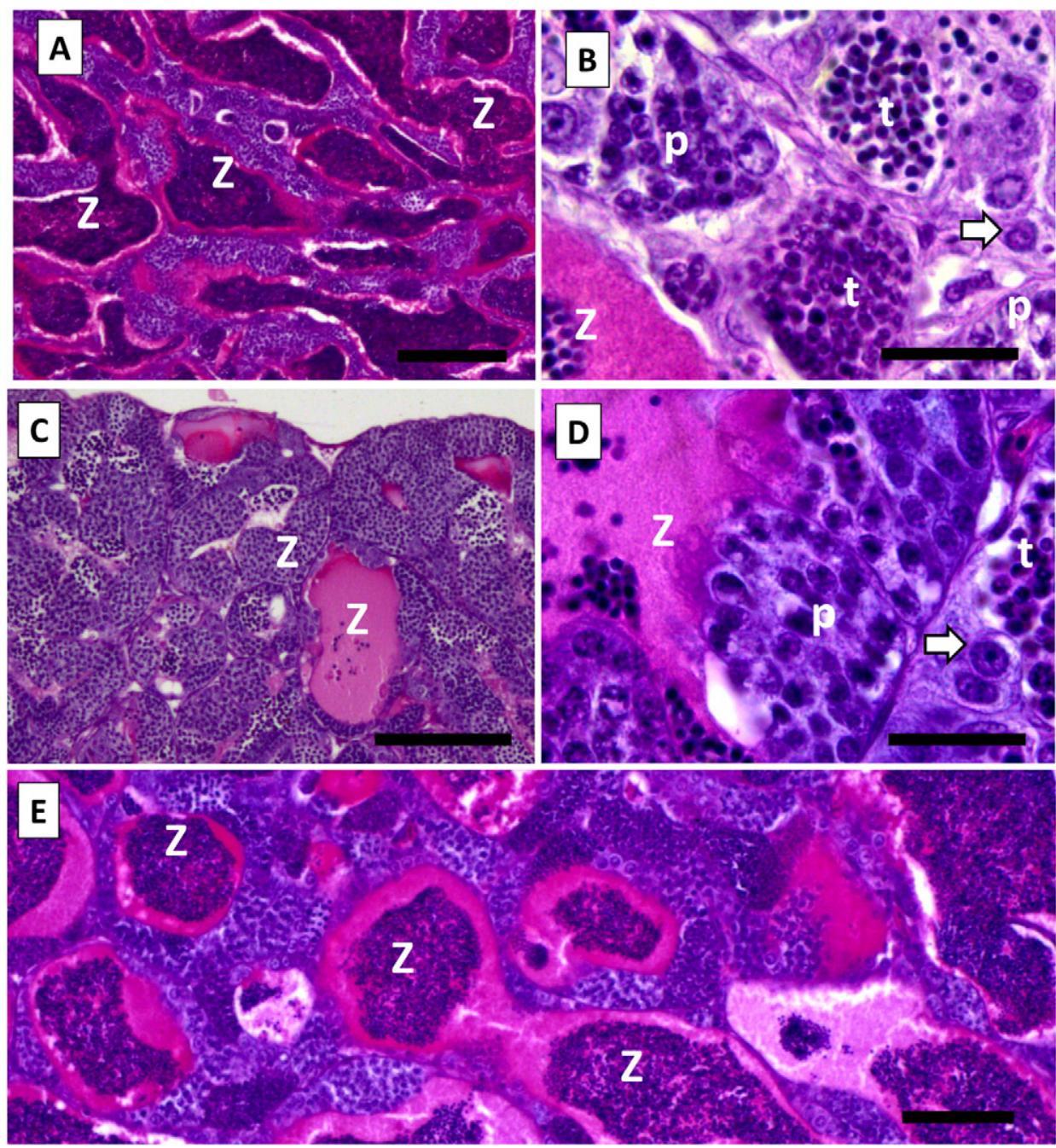

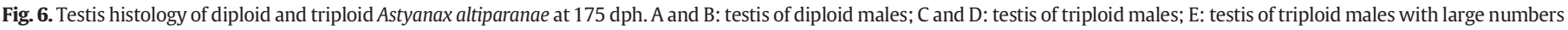
of spermatozoa. Arrows: spermatogonia; p: spermatocytes; t: spermatids; and z: spermatozoa. Scale A: $100 \mu \mathrm{m} ; \mathrm{B}: 20 \mu \mathrm{m} ; \mathrm{C}: 200 \mu \mathrm{m}$; D: $20 \mu \mathrm{m}$; E: $100 \mu \mathrm{m}$.

observed in diploid females, indicating sexual maturation. According to Werner et al. (2008), sterilization can positively affect the yield of the fillet through muscle hypertrophy, which may also have occurred in this study.

Triploid males often show growth similar to diploids (Dunham, 2004; Peruzzi et al., 2009; Feindel et al., 2010; Kizak et al., 2013). In this study, although triploid males present higher weight, the carcass yield of males was similar in both ploidy levels, which are probably associated with the similarity in GSI. In the gonad histology, although the majority of the 53 triploid males showed few spermatozoa, six exhibited testicular development similar to diploids, confirming potential fertility in triploid males, as has been reported by other authors (Linhart et al., 2006). However, the semen of triploid males may be aneuploid and differ from diploids in spermatozoon concentration and morphology (Linhart et al., 2006; Fujimoto et al., 2008; Flajšhans et al., 2010; Hamasaki et al., 2013). Additionally, when oocytes are fertilized with aneuploid spermatozoa, the resultant eggs may present lower fertility or give rise to unviable offspring (Peruzzi et al., 2009; Feindel et al., 2010).

Triploid female sterility has been reported in several species (Trippel et al., 2008; Piferrer et al., 2009; Benfey, 2015). Hamasaki et al. (2013) observed that triploid male and female Takifugu niphobles produced small numbers of abnormal gametes, and, after fertilization, no eggs survived. In A. altiparanae, the histology showed that triploid females possessed immature gonads. Even though a few vitellogenic oocytes were found in the gonads of some triploid females, those gonads do not ensure reproduction, and triploid female A. altiparanae appeared to be sterile.

The presence of spines, especially in the anal fin, is widely used to differentiate A. altiparanae males from females (Porto-Foresti et al., 2005). Spines were evident in males of both ploidy levels in the present study. Neither diploid nor triploid females showed significant development of anal or pelvic spines. The function of such spines is unknown. Azevedo et al. (2000) hypothesized that they are related to courtship behavior. Thus, as the triploid males showed gonad development similar to diploid males, and the spines appeared after sexual maturation, we hypothesized that such structures are associated with reproduction, possibly stimulating female spawning.

The sex ratios showed more males in the triploid fish, as observed for channel catfish (Ictalurus punctatus) (Goudie et al., 1995) and turbot (Scophthalmus maximus) (Cal et al., 2010). However, in the view of the advantage of triploid females (sterility and increased carcass yield), techniques such as the use of masculinized tetraploid females may be used to guarantee future monosex production of triploid females.

Carcass fatty acid composition may be influenced by factors such as feeding, time of year, water quality, ploidy, and species (Buchtova et al., 2004; Flajšhans et al., 2010). In the present study, no differences were observed in fatty acid composition of diploid and triploid males. In females, differences were observed, as events related to reproduction demand larger amounts of energy from fatty acids (Turchini et al., 2009), which was confirmed in A. altiparanae by Gonçalves et al. (2014). 
Table 1

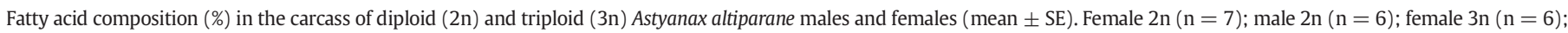
male $3 n(n=6)$.

\begin{tabular}{|c|c|c|c|c|c|c|c|}
\hline \multirow[t]{2}{*}{ Index (\%) } & \multirow[t]{2}{*}{ Female $2 \mathrm{n}$} & \multirow[t]{2}{*}{ Male $2 \mathrm{n}$} & \multirow[t]{2}{*}{ Female $3 n$} & \multirow[t]{2}{*}{ Male 3n } & \multicolumn{3}{|l|}{$P$-value } \\
\hline & & & & & Sex & Ploidy & Interaction \\
\hline \multicolumn{8}{|c|}{ Saturated fatty acids } \\
\hline $\mathrm{C} 12: 0$ & $0.04 \pm 0.01$ & $0.04 \pm 0.01$ & $0.03 \pm 0.01$ & $0.04 \pm 0.01$ & 0.9643 & 0.5042 & 0.5042 \\
\hline $\mathrm{C} 14: 0$ & $1.67 \pm 0.07$ & $1.57 \pm 0.05$ & $1.50 \pm 0.05$ & $1.56 \pm 0.03$ & 0.9083 & 0.0531 & 0.0891 \\
\hline C15:0 & $0.44 \pm 0.06^{\mathrm{a}}$ & $0.45 \pm 0.04^{\mathrm{a}}$ & $0.32 \pm 0.03^{b}$ & $0.38 \pm 0.01^{\mathrm{ab}}$ & 0.2471 & 0.0088 & 0.3072 \\
\hline $\mathrm{C} 16: 0$ & $23.23 \pm 0.48^{\mathrm{a}}$ & $22.04 \pm 0.42^{\mathrm{ab}}$ & $21.5 \pm 0.16^{\mathrm{b}}$ & $21.44 \pm 0.08^{\mathrm{b}}$ & 0.0657 & 0.0051 & 0.1644 \\
\hline $\mathrm{C} 17: 0$ & $0.69 \pm 0.08$ & $0.70 \pm 0.04$ & $0.55 \pm 0.04$ & $0.60 \pm 0.01$ & 0.2666 & 0.0587 & 0.3543 \\
\hline C18:0 & $9.48 \pm 0.09$ & $9.53 \pm 0.08$ & $9.51 \pm 0.15$ & $9.30 \pm 0.04$ & 0.9605 & 0.0861 & 0.5390 \\
\hline C $20: 0$ & $0.29 \pm 0.01^{\mathrm{ab}}$ & $0.32 \pm 0.01^{\mathrm{a}}$ & $0.26 \pm 0.01^{\mathrm{b}}$ & $0.29 \pm 0.01^{\mathrm{a}}$ & 0.0008 & 0.0045 & 0.5735 \\
\hline $\mathrm{SFA}_{\text {sum }}$ & $35.89 \pm 0.59^{a}$ & $34.71 \pm 0.50^{\mathrm{ab}}$ & $33.7 \pm 0.27^{\mathrm{b}}$ & $33.65 \pm 0.08^{b}$ & 0.2193 & 0.0009 & 0.1574 \\
\hline \multicolumn{8}{|c|}{ Mono-unsaturated fatty acids } \\
\hline $\mathrm{C} 14: 1$ & $0.06 \pm 0.01$ & $0.05 \pm 0.01$ & $0.06 \pm 0.01$ & $0.06 \pm 0.01$ & 0.1748 & 0.7815 & 0.1748 \\
\hline C16:1 & $3.03 \pm 0.13$ & $2.95 \pm 0.06$ & $2.98 \pm 0.02$ & $3.06 \pm 0.02$ & 0.7409 & 0.5282 & 0.5910 \\
\hline C $17: 1$ & $0.37 \pm 0.02$ & $0.38 \pm 0.03$ & $0.32 \pm 0.01$ & $0.37 \pm 0.01$ & 0.0714 & 0.1419 & 0.1873 \\
\hline c18:1n9c & $34.59 \pm 2.32^{\mathrm{b}}$ & $36.16 \pm 1.02^{\mathrm{b}}$ & $41.25 \pm 1.21^{\mathrm{a}}$ & $39.00 \pm 0.15^{\mathrm{ab}}$ & 0.4664 & 0.0012 & 0.0848 \\
\hline C18:1n7 & $2.23 \pm 0.07^{\mathrm{a}}$ & $2.09 \pm 0.06^{\mathrm{a}}$ & $1.77 \pm 0.11^{\mathrm{b}}$ & $2.11 \pm 0.05^{\mathrm{a}}$ & 0.1189 & 0.0022 & 0.0011 \\
\hline C20:1n9 & $0.69 \pm 0.02^{\mathrm{b}}$ & $0.84 \pm 0.02^{\mathrm{a}}$ & $0.84 \pm 0.01^{\mathrm{a}}$ & $0.88 \pm 0.01^{\mathrm{a}}$ & 0.0000 & 0.0000 & 0.0031 \\
\hline $\mathrm{C} 24: 1 \mathrm{n} 9$ & $0.45 \pm 0.06$ & $0.49 \pm 0.03$ & $0.38 \pm 0.05$ & $0.40 \pm 0.01$ & 0.1631 & 0.6539 & 0.7010 \\
\hline MUFA $_{\text {sum }}$ & $41.42 \pm 2.25^{\mathrm{a}}$ & $42.96 \pm 0.92^{\mathrm{a}}$ & $47.59 \pm 1.07^{b}$ & $45.87 \pm 0.13^{\mathrm{ab}}$ & 0.5593 & 0.0012 & 0.1070 \\
\hline \multicolumn{8}{|c|}{ Poly-unsaturated fatty acids } \\
\hline $\mathrm{C} 18: 2 \mathrm{n} 6 \mathrm{c}$ & $11.82 \pm 0.66^{\mathrm{a}}$ & $11.10 \pm 0.29^{\mathrm{ab}}$ & $10.01 \pm 0.12^{\mathrm{b}}$ & $11.16 \pm 0.20^{\mathrm{ab}}$ & 0.6699 & 0.0194 & 0.0135 \\
\hline$C 18: 3 n 6$ & $0.16 \pm 0.02^{\mathrm{a}}$ & $0.14 \pm 0.01^{\mathrm{ab}}$ & $0.09 \pm 0.01^{\mathrm{b}}$ & $0.13 \pm 0.01^{\mathrm{ab}}$ & 0.5923 & 0.0063 & 0.0593 \\
\hline$C 18: 3 n 3$ & $1.22 \pm 0.22^{\mathrm{ab}}$ & $1.49 \pm 0.19^{\mathrm{a}}$ & $0.80 \pm 0.09^{b}$ & $1.15 \pm 0.05^{\mathrm{ab}}$ & 0.0354 & 0.0263 & 0.9185 \\
\hline C18:2c9.t11 & $0.21 \pm 0.04$ & $0.24 \pm 0.03$ & $0.15 \pm 0.01$ & $0.19 \pm 0.01$ & 0.1397 & 0.0518 & 0.9591 \\
\hline C18:2t10.c12 & $0.02 \pm 0.01$ & $0.02 \pm 0.01$ & $0.02 \pm 0.01$ & $0.02 \pm 0.01$ & 0.9766 & 0.6607 & 0.6607 \\
\hline $\mathrm{C} 20: 2$ & $0.41 \pm 0.06$ & $0.46 \pm 0.03$ & $0.26 \pm 0.01$ & $0.40 \pm 0.01$ & 0.1166 & 0.0665 & 0.9971 \\
\hline$C 20: 3 n 6$ & $0.5 \pm 0.07^{\mathrm{a}}$ & $0.38 \pm 0.02^{\mathrm{ab}}$ & $0.28 \pm 0.02^{\mathrm{b}}$ & $0.33 \pm 0.01^{\mathrm{b}}$ & 0.2809 & 0.0009 & 0.0224 \\
\hline $\mathrm{C} 20: 4 \mathrm{n} 6$ & $1.44 \pm 0.33$ & $1.38 \pm 0.11$ & $0.75 \pm 0.10$ & $1.06 \pm 0.02$ & 0.4638 & 0.0709 & 0.3018 \\
\hline$C 20: 3 n 3$ & $0.10 \pm 0.02$ & $0.12 \pm 0.01$ & $0.08 \pm 0.01$ & $0.09 \pm 0.01$ & 0.1421 & 0.0967 & 0.6665 \\
\hline$C 20: 5 n 3$ & $0.90 \pm 0.05^{\mathrm{a}}$ & $0.92 \pm 0.05^{\mathrm{a}}$ & $0.72 \pm 0.03^{b}$ & $0.85 \pm 0.03^{\mathrm{ab}}$ & 0.0528 & 0.0124 & 0.2508 \\
\hline $\mathrm{C} 22: 4 \mathrm{n} 6$ & $0.24 \pm 0.06$ & $0.21 \pm 0.03$ & $0.12 \pm 0.02$ & $0.16 \pm 0.01$ & 0.7807 & 0.0595 & 0.2559 \\
\hline C $22: 5 n 6$ & $0.49 \pm 0.16$ & $0.53 \pm 0.05$ & $0.25 \pm 0.06$ & $0.37 \pm 0.01$ & 0.3469 & 0.0567 & 0.6819 \\
\hline C22:6n3 & $5.19 \pm 0.86$ & $5.38 \pm 0.36$ & $3.73 \pm 0.41$ & $4.58 \pm 0.14$ & 0.3069 & 0.0513 & 0.5011 \\
\hline PUFA n6 $6_{\text {sum }}$ & $14.65 \pm 1.88^{\mathrm{a}}$ & $13.74 \pm 1.77^{\mathrm{ab}}$ & $11.50 \pm 1.62^{b}$ & $13.21 \pm 1.80^{\mathrm{ab}}$ & 0.5904 & 0.0033 & 0.0270 \\
\hline PUFA n $3_{\text {sum }}$ & $7.41 \pm 1.14^{\mathrm{ab}}$ & $7.91 \pm 1.68^{\mathrm{a}}$ & $5.33 \pm 0.81^{\mathrm{b}}$ & $6.67 \pm 1.00^{\mathrm{ab}}$ & 0.1401 & 0.0162 & 0.5323 \\
\hline PUFA $_{\text {sum }}$ total & $22.70 \pm 2.10^{\mathrm{a}}$ & $22.37 \pm 0.73^{\mathrm{a}}$ & $16.83 \pm 0.77^{\mathrm{b}}$ & $20.50 \pm 0.18^{\mathrm{ab}}$ & 0.0738 & 0.0158 & 0.1851 \\
\hline Ratio n-6/n-3 & $1.98^{\mathrm{ab}}$ & $1.74^{\mathrm{b}}$ & $2.16^{\mathrm{a}}$ & $1.98^{\mathrm{ab}}$ & 0.0116 & 0.1029 & 0.7151 \\
\hline
\end{tabular}

SE: standard error. Data are show as mean \pm SE. Different letters and $P$-values in bold indicate significant difference $($ ANOVA; $P<0.05)$.

Therefore, the inadequate gonad development in triploid females may have considerably influenced their fatty acid profile. Saturated fatty acids are important for the development, structure and function of cell membranes (Ng and Wang, 2011) and, in the present study, diploid females showed higher proportions of these fatty acids. In rainbow trout Oncorhynchus mykiss, Manor et al. (2012) observed that egg development was associated with a reduction of fatty acids in adipose tissue of the muscle and especially in the organs. Therefore, the same event could be occurring in A. altiparanae diploid females, where the fatty acids for gonad development were probably supplied by the viscera.

Triploid females exhibited greater quantities of MUFAs. Oleic acid (C18:1n9) fatty acid was significantly lower in diploid females. Ribeiro et al. (2012) observed that MUFAs, especially oleic acid, were relocated to the post-ovulatory ovaries in rainbow trout. Henderson et al. (1984) reported that fish require oleic acid for ovulation and spawning. Therefore, the difference observed in MUFA content of diploid and triploid females was probably due to allocation for ovarian development and ovulation.

Poly-unsaturated fatty acids were observed in larger quantities in diploid females. Similar results were observed by Buchtova et al. (2004) in 42 month-old Tinca tinca. Triploid rainbow trout females are sterile and do not accumulate fatty acids in the muscle (Ribeiro et al., 2012). Similarly to observe by Ribeiro et al. (2012), where $n 3$ fatty acids is found in higher quantities in the muscle of diploid females, the higher amounts $n 6$ fatty acids observed in the carcass of $A$. altiparanae diploid females are probably due to the importance of such fatty acids in the process of final maturation, being posteriorly available to the gonads (Bell and Tocher, 1995).
Poly-unsaturated fatty acids, especially omega-3 and omega-6, are important for aquaculture, as they influence the marketability and nutritional value of the fillet (Manor et al., 2012). In this study, the fish of all treatments presented a higher PUFA/SFA ratio (0.45) than recommended for human consumption (HMSO, 1994). The low proportions of omega- 3 and 6 poly-unsaturated fatty acids in triploid females may be increased by diet supplementation, as observe in Nile tilapia Oreochromis niloticus (Navarro et al., 2012), in which supplementation with vitamin E promoted an increase in the PUFA/SFA ratio and high proportions of omega 3 and 6 fatty acids. Additionally, fatty acid proportions could potentially vary throughout the year (Manor et al., 2012); hence the advantages presented by diploid females at $175 \mathrm{dph}$ may be seasonal, and should be further evaluated.

As females are larger than males in A. altiparanae and triploid females are sterile and showed increased carcass yield, the generation of $100 \%$ triploid female offspring is suggested in this species to increase production, improve marketability and reduce the risk of introgression.

\section{Acknowledgements}

The authors thank the Conselho Nacional de Desenvolvimento Científico e Tecnológico (CNPq 130417/2013-0) for the Master's scholarship; the Centro de Aquicultura da UNESP (CAUNESP), FAPESP (JP-FAPESP 2010/17429-1), CEPTA/ICMBio for providing the fish; and the FCAV/UNESP (Faculdade de Ciências Agrárias e Veterinárias) for assistance with fatty acid analysis. 


\section{References}

Adamov, N.S.D.M., Nascimento, N.F.D., Maciel, E.C.S., Pereira-Santos, M., Senhorini, J.A Calado, L.L., Evangelista, M.M., Nakaghi, L.S.O., Guerrero, A.H.M., Fujimoto, T., Yasui, G.S., 2016. Triploid induction in the yellowtail tetra, Astyanax altiparanae, using temperature shock: tools for conservation and aquaculture. J. World Aquacult. Soc. (n/a$\mathrm{n} / \mathrm{a})$.

Arai, K., 2001. Genetic improvement of aquaculture finfish species by chromosome manipulation techniques in Japan. Aquaculture 197, 205-228.

Azevedo, M.A., Malabarba, L.R., Fialho, C.B., 2000. Reproductive biology of the inseminating glandulocaudine Diapoma speculiferum Cope (Teleostei: Characidae). Copeia 2000, 983-989.

Bell, M.V., Tocher, D.R., 1995. Biosynthesis of polyunsatured fatty acids in aquatic ecosystems: general patways and new directions. In: Arts, M.T., Bret, M.T., Kainz, M.J. (Eds.) Lipid in Aquatic Ecosystems. Springer Science, New York.

Benfey, T.J., 2015. Effectiveness of triploidy as a management tool for reproductive containment of farmed fish: atlantic salmon (Salmo salar) as a case study. Rev. Aquac.

Bligh, E.G., Dyer, W.J., 1959. A rapid method of total lipid extraction and purification. Can. J. Biochem. Physiol. 37, 911-917.

Buchtova, H., Smutna, M., Vorlova, L., Svobodova, Z., Flajshans, M., 2004. Fatty acid composition of diploid and triploid populations of tench (Tinca tinca L.). Acta Vet. Brno 73, 235-245.

Cal, R., Terrones, J., Vidal, S., Martinez, P., Piferrer, F., 2010. Differential incidence of gonadal apoptosis in triploid-induced male and female turbot (Scophthalmus maximus). Aquaculture 307, 193-200.

Dunham, R.A., 2004. Aquaculture and Fisheries Biotechnology: Genetic Approaches. GABI Publishing, Oxford.

Feindel, N.J., Benfey, T.J., Trippel, E.A., 2010. Competitive spawning success and fertility of triploid male Atlantic cod (Gadus morhua). Aquac. Environ. Interact. 1, 47-55.

Firestone, D., 2009. American Oil Chemists' Society Official Methods and Recommended Practices. AOCS Press, Urbana, IL.

Flajšhans, M., Gela, D., Kocour, M., Buchtová, H., Rodina, M., Pšenička, M., Kašpar, V., Piačková, V., Sudová, E., Linhart, O., 2010. A review on the potential of triploid tench for aquaculture. Rev. Fish Biol. Fish. 20, 317-329.

Foresti, F., Oliveira, C., Carvalho, E.D., 1994. Ploidy evaluation in the pacu fish, Piaractus mesopotamicus (Pisces, Characiformes): techniques and comments. Rev. Bras. Biol. $54,31-37$.

Friars, G.W., McMillan, I., Quinton, V.M., O'Flynn, F.M., McGeachy, S.A., Benfey, T.J., 2001. Family differences in relative growth of diploid and triploid Atlantic salmon (Salmo salar L.). Aquaculture 192, 23-29.

Fujimoto, T., Yasui, G.S., Yoshikawa, H., Yamaha, E., Arai, K., 2008. Genetic and reproductive potential of spermatozoa of diploid and triploid males obtained from interspecific hybridization of Misgurnus anguillicaudatus female with M. mizolepis male. J. Appl. Ichthyol. 24, 430-437.

Garutti, V., 1990. Caráter sexual secundário em Astyanax bimaculatus (Ostariophysi, Characidae), relacionado às nadadeiras anal e pélvicas. Naturalia 15, 109-119.

Garutti, V., 2003. Piscicultura ecológica (UNESP).

Golpour, A., Siddique, M.A.M., Siqueira-Silva, D.H., Pšenicka, M., 2016. Induced sterility in fish and its potential and challenges for aquaculture and germ cell transplantation technology: a review. Biologia 71, 853-864.

Gonçalves, L.U., Parisi, G., Bonelli, A., Sussel, F.R., Viegas, E.M.M., 2014. The fatty acid compositions of total, neutral and polar lipids in wild and farmed lambari (Astyanax altiparanae) (Garutti \& Britski, 2000) broodstock. Aquac. Res. 45, 195-203.

Goudie, C.A., Simco, B.A., Davis, K.B., Liu, Q., 1995. Production of gynogenetic and polyploid catfish by pressure-induced chromosome set manipulation. Aquaculture 133, 185-198.

Hamasaki, M., Takeuchi, Y., Miyaki, K., Yoshizaki, G., 2013. Gonadal development and fertility of triploid grass puffer Takifugu niphobles induced by cold shock treatment. Mar. Biotechnol. 15, 133-144.

Henderson, R.J., Sargent, J.R., Hopkins, C.C.E., 1984. Changes in the content and fatty acid composition of lipid in an isolated population of the capelin, Mallotus villosus, during sexual maturation and spawning. Mar. Biol. 78.

HMSO, U., 1994. Nutritional Aspects of Cardiovascular Disease (Report on Health and Social Subjects No. 46). HMSO, London.
Huergo, G.M., Zaniboni-Filho, E., 2006. Triploidy induction in jundia, Rhamdia quelen (Quoy \& Gaimard, 1824), through hydrostatic pressure shock. J. Appl. Aquac. 18, $45-57$.

Kizak, V., Guner, Y., Turel, M., Kayim, M., 2013. Comparison of growth performance, gonadal structure and erythrocyte size in triploid and diploid brown trout (Salmo trutta fario L, 1758). Turk. J. Fish. Aquat. Sci. 13, 571-580.

Koedprang, W., Nakorn, U.N., 2000. Preliminary study on performance of triploid Thai silver barb, Puntius gonionotus. Aquaculture 190, 211-221.

Linhart, O., Rodina, M., Flajshans, M., Mavrodiev, N., Nebesarova, J., Gela, D., Kocour, M., 2006. Studies on sperm of diploid and triploid tench, Tinca tinca (L.). Aquac. Int. 14, $9-25$.

Lutz, C.G., 2003. Practical Genetics for Aquaculture. Blackwell, London.

Manor, M.L., Weber, G.M., Salem, M., Yao, J., Aussanasuwannakul, A., Kenney, P.B., 2012. Effect of sexual maturation and triploidy on chemical composition and fatty acid content of energy stores in female rainbow trout, Oncorhynchus mykiss. Aquaculture 312-321.

Navarro, R.D., Navarro, F.K.S.P., Ribeiro Filho, O.P., Ferreira, W.M., Pereira, M.M., Seixas Filho, J.T., 2012. Quality of polyunsaturated fatty acids in Nile tilapias (Oreochromis niloticus) fed with vitamin E supplementation. Food Chem. 134, 215-218.

Ng, W.K., Wang, Y., 2011. Inclusion of crude palm oil in the broodstock diets of female Nile tilapia, Oreochromis niloticus, resulted in enhanced reproductive performance compared to broodfish fed diets with added fish oil or linseed oil. Aquaculture 314, $122-131$

Pereira-Santos, M., Yasui, G., Xavier, P., de Macedo, A.N., do Nascimento, N., Fujimoto, T., Senhorini, J., Nakaghi, L., 2016. Morphology of gametes, post-fertilization events and the effect of temperature on the embryonic development of Astyanax altiparanae (Teleostei, Characidae). Zygote 1-13 (Cambridge, England).

Peruzzi, S., Rudolfsen, G., Primicerio, R., Frantzen, M., Kauric, G., 2009. Milt characteristics of diploid and triploid Atlantic cod (Gadus morhua L). Aquac. Res, 40, 1160-1169.

Piferrer, F., Beaumont, A., Falguiere, J.-C., Flajshans, M., Haffray, P., Colombo, L., 2009. Polyploid fish and shellfish: production, biology and applications to aquaculture for performance improvement and genetic containment. Aquaculture 293, 125-156.

Poontawee, K., Werner, C., Müller-Belecke, A., Hörstgen-Schwark, G., Wicke, M., 2007. Flesh qualities and muscle fiber characteristics in triploid and diploid rainbow trout. J. Appl. Ichthyol. 23, 273-275.

Porto-Foresti, F, Castilho-Almedia, R.B.,Foresti, F, 2005. Biologia e criação do lambari-dorabo-amarelo (Astyanax altiparanae). In: Baldisserto, B., Gomes, L.C. (Eds.), Espécies nativas para piscicultura no Brasil. UFSM, Santa Maria, pp. 105-120.

Potthoff, T., 1984. Clearing and staining techniques. In: Moser, H.G. (Ed.), Ontogeny and Systematics of Fishes. Allen Press, Lawrence, KS, USA, pp. 35-37.

Ribeiro, C.S., Gomes, A.D., Vieira, V.A.R.O., Tabata, Y.A., Takahashi, N.S., Moreira, R.G., 2012. The effect of ploidy on the fatty acid profile during the reproductive cycle of female rainbow trout (Oncorhynchus mykiss). Aquac. Int. 20, 1117-1137.

Sacobie, C.F.D., Glebe, B.D., Barbeau, M.A., Lall, S.P., Benfey, T.J., 2012. Effect of strain and ploidy on growth performance of Atlantic salmon, Salmo salar, following seawater transfer. Aquaculture 334, 58-64.

Siqueira-Silva, D.H., Silva, A.P., Ninhaus-Silveira, A., Verissimo-Silveira, R., 2015. The effects of temperature and busulfan (Myleran) on the yellowtail tetra Astyanax altiparanae (Pisces, Characiformes) spermatogenesis. Theriogenology 84, 1033-1042.

Trippel, E.A. Benfey, T.J. Neil, S.R., Cross, N., Blanchard, M.J., Powell, F., 2008. Effects of continuous light and triploidy on growth and sexual maturation in Atlantic cod, Gadus morhua. Cybium 32, 136-138.

Turchini, G.M., Torstensen, B.E., Ng, W.K., 2009. Fish oil replacement in finfish nutrition. Rev. Aquac. 1, 10-57.

Werner, C., Poontawee, K., Mueller-Belecke, A., Hoerstegen-Schwark, G., Wicke, M., 2008. Flesh characteristics of pan-size triploid and diploid rainbow trout (Oncorhynchus mykiss) reared in a commercial fish farm. Arch. Tierz. 51, 71-83.

Yasui, G.S., Senhorini, J.A., Shimoda, E., Pereira-Santos, M., Nakaghi, L.S.O., Fujimoto, T., Arias-Rodriguez, L., Silva, L.A., 2015. Improvement of gamete quality and its shortterm storage: an approach for biotechnology in laboratory fish. Animal 9, 464-470.

Zaganini, R.L., Hashimoto, D.T., Pereira, L.H.G. Oliveira, C., Mendonca, F.F. Foresti, F. Porto-Foresti, F., 2012. Isolation and characterization of microsatellite loci in the neotropical fish Astyanax altiparanae (Teleostei: Characiformes) and cross-species amplification. J. Genet. 91, E24. 